Meta

Journal des traducteurs

Translators' Journal

\title{
Translation: Sub Specie of Culture
}

\section{Vladimir Nikolayevich Toporov}

Volume 37, numéro 1, mars 1992

La traduction en Russie : théorie et pratique / Translation in Russia: Theory and Practice

URI : https://id.erudit.org/iderudit/004495ar

DOI : https://doi.org/10.7202/004495ar

Aller au sommaire du numéro

Éditeur(s)

Les Presses de l'Université de Montréal

ISSN

0026-0452 (imprimé)

1492-1421 (numérique)

Découvrir la revue

Citer cet article

Toporov, V. N. (1992). Translation: Sub Specie of Culture. Meta, 37(1), 29-49. https://doi.org/10.7202/004495ar

\section{Résumé de l'article}

On présente deux articles traitant de la rencontre de deux ou de plusieurs langues (textes et cultures) à l'intérieur d'un espace culturel défini. On cite un exemple d'une traduction d'un texte étranger qui est non seulement traduit dans la langue du pays mais également dans le système de valeurs nationales, et ce, sans mention du fait qu'il s'agit d'une traduction. 


\title{
TRANSLATION: SUB SPECIE OF CULTURE
}

\author{
VLADIMIR NIKOLAYEVICH TOPOROV \\ Institute of Slavonic and Balkan Studies, \\ USSR Academy of Sciences, Moscow, USSR
}

Résumé

On présente deux articles traitant de la rencontre de deux ou de plusieurs langues (textes et cultures) à l'intérieur d'un espace culturel défini. On cite un exemple d'une traduction d'un texte étranger qui est non seulement traduit dans la langue du pays mais également dans le système de valeurs nationales, et ce, sans mention du fait qu'il s'agit d'une traduction.

A detailed discussion of the link between translation and culture is beyond the purport of this article. But it would not be irrelevant to look at how translation is seen from the point of view of culture interpreted as a succession of historical "accomplishments" in creating new and higher types of spirituality.

The concept of "translation", engendered within culture by its own internal needs, is inconceivable ${ }^{1}$ without it. However, the meaning of that concept acquires added depth when the problem of "translation" is seen within a broader context than is customary. The point is that translation is not merely an important fact and motive force of culture, an impulse and at the same time a method of "fostering" culture, but it is a key principle of culture itself, its solid foundation. Wherever that principle does not work, culture dies, becomes degraded, or gives way to another culture. This being so, the approach to any of the two poles - extreme isolation from everything "alien" and autarchy (the absence of translations) or an extreme degree of merger with what is foreign (a maximum of translations), i.e., "no-translation" versus "all-translation," signals a danger, a disruption of the functioning of translation in its natural framework and consequently a crisis of culture in its very core due to the deformation of the principle of that culture, i.e., translation from an alien idiom into one's own and from one's own into a foreign one. History offers a good many illustrations of each of these two types of danger for culture. Fortunately, the majority of cultures when faced with such threatening situations, manage to make the principle of "translation" and its mechanisms work on a scale that ensures normal functioning of culture (by normal we mean a certain minimally sufficient level). In one case culture rescues itself from isolation by assimilating the "foreign" through translation; in the other case it seeks salvation from the bondage of the "foreign" by constituting the "native." In either case, however, "native" and "foreign" are in a certain relationship which, though not invariably harmonious, is nearly always "reasonable," i.e., meeting certain criteria.

It goes without saying that translation is never quite a fact of only one ("translating") culture: it is always bilateral or multilateral and, even by definition, it links two languages, two texts, two cultures ("native" and "foreign") and ensures exchange of information - linguistic, textual, "cultural" — primarily at the level of corresponding values. 2 Therefore, any encounter in the cultural space is potentially a "translation" situation. Culture puts forward its own challenges and finds its own 
responses to them (in the same way as it happens, according to Arnold Toynbee, in historical civilizations) and these responses often lie in the process of broad intercultural translations. A culture's "rating" is increasingly determined by its ability to assimilate "things foreign," by the pluralism of meanings and forms and the predominance of the "cumulative" principle.

The two articles below are devoted to such encounters in the cultural space (the theoretical aspect of the problem) and cite a concrete example of a translation when a "foreign" text is translated not only into a "native" language, but, most important, into a "native" system of values, while the very fact of it being a translation may or may not be declared to the audience.

\section{I-ENCOUNTERS IN CULTURAL SPACE}

Who knows, perhaps at this very moment

Some Japanese is translating me

Into Turkish.

And is looking into my soul.

These lines were written by Mandelshtam in 1933, the last year when his poetry was still being published. They refer to a situation which at the time appeared not only wildly unrealistic and fantastic, but absurd and suicidally dangerous. These lines record a "mental" experiment that is providential and prophetic if one thinks of the personal tragedy that was in store for the poet (My lips will be sealed with lead). Mandelshtam earned the right to stage such an experiment and it would be wrong to see it as mere play and to overlook the main (though far-fetched) message - the idea of the brotherhood of man realizing itself through translation and creating new forms of its existence and intimate communication between "native" and "foreign," from soul to soul - also through translation. Forcible separation of souls, the blocking of exchange of cultural values and meanings doom one to muteness and isolation which, in turn, paralyze the soul of culture and endanger the idea of the brotherhood of man - both the inherent brotherhood bestowed on man at the start of his natural path and more especially the future that is created by man's cultural endeavour step by step. The power of taboos is deadly but still it cannot eliminate the need for a listener, reader, interlocutor, ${ }^{3}$ for conversation, for two-way exchange and communication.

A "longing for world culture" of which the poet wrote, became more acute and more painful because his voice did not reach those to whom it was addressed (our words are not audible within ten steps), because his poetry was not read in his country (you chaffed me and you didn't read me...), because the sound shrank and the air was drained, because Night that is and will be is on the doorstep. In a situation of the cataclysm of culture and human forms of its existence, in a situation of the rupture of the spiritual world and growing threat to the very spirit of life, the poet is looking for ways to fulfill the mission which he never doubted just as he never doubted the spiritual values of culture. He considers various options, even abandoning his own language ( $I$ want to be out of our speech and Foreign speech will be my shell). But all these options involve a belief in the intransigent significance of culture, its fundamental humanity, its diversity, for culture lives both by what is "native" and what is "foreign," the alliance or clash between the two contributing to the growth of culture. Culture therefore invariably invites comparison and juxtaposition; it is not only the place where meanings are born, but the space in which they are being exchanged, "transmitted" and seek to be translated from one cultural language into another. That is why even abandoning native speech does not cancel the culture to which it belongs, but merely defines its meanings on a new scale 
offered by the "foreign" language. (Witness the Russian poet's fantasy about a Japanese translating his poetry into Turkish.) All these variants are different only on the surface and underlying all of them is the profound conviction that any culture is "conductive" with regard to the meanings of another culture ("meaning-conductive"). The optimal "conductivity" of meanings - from one culture to another, from one person to another, from "I" to "You" is essentially the "superconductivity" (if only potential and ideal) about which the poet wrote (Tartars, Uzbeks, and Nentsy/the whole Ukrainian people/ even the Germans of the Volga/ await their translators). The almost apocalyptic wish and anticipation of being translated and seeing oneself in the mirror of a "foreign language and a "foreign" culture, even expressed in such exaggerated and grotesque forms, afford an insight into the innermost motive of culture of which the carriers of culture and its students are not always aware, viz., the need to communicate with other cultures, to be reflected in them and to reflect a "foreign" culture in one's own.

Creative periods in the development of culture have no use for petty accounts and tend to take a broad view of the boundaries between what is "native" and what is "foreign." The formulation of the rights of property can never keep up with the actual bold conquests and even with correct acquisitions from "foreign" cultures. These creative periods of culture are, as a rule, oriented towards "superconductivity" (although they often overrate their potential in that respect). Therefore, they always deal (directly or indirectly) with a comparison of "native" and "foreign," a comparison of the values of different cultures. Relating and comparing this and that, the native and the foreign constitutes a fundamental and abiding concern of culture because comparison, when broadly interpreted (as any translation - from language to language, from one space to another, from one time to another, from one culture to another), is intimately connected with man's existence in the semiotic space of culture, with its pivotal problem of identity and difference, and with the function of culture. Mandelshtam formulates this problem most strikingly in his rough draft of "A Conversation About Dante" in which he writes:

I compare, therefore I am, Dante might have said. He was the Descartes of the metaphor. Because our consciousness (and who knows of any other?) discovers matter only through metaphor, for there is no being without comparison, being itself is comparison. ${ }^{4}$

(Emphasis added - V.T.)

The problem of identity and difference (lack of identity) indicated above has a direct bearing on culture. The ability to carry out the operations of identification and distinction, while being a means and an instrument of orientation in the cultural space, is at the same time an important gain of culture, its major asset. That problem wouldn't exist if things were as simple as the principle "this - this" ("yes - yes"), or "this - not this," i.e. "that" ("no - no"). But this, far from facilitating the human condition, would have complicated it many times over. Serious, sometimes harsh, requirements are presented to the individual and to the whole human race, and this in itself testifies to a high evaluation of man's potential and confidence in man. The underlying idea is not of tutelage, but of man's independence, his responsibility to himself, life, and its higher meaning, his initiative. The surrounding world conveys many messages to man and it can convey even more. But nature's "signs" are polysemantic, 5 and need to be interpreted from the functional point of view. The problem is even more acute in the sphere of man's cultural being, in the semiotic cultural system, the area of man's evolution where he has achieved the greatest success. But while it is easy to develop an understanding of the meaning of signs and to learn to use them (through education, training, imperatives imposed by the community, etc.) the same cannot be said so easily about the problem of identity and difference: it is more complex and more intricate, and, unlike the ability to 
use cultural signs, may not belong to the conditiones sine qua non of human existence; by the same token, it confers special advantages and faces man with a different set of challenges to which he does not always rise. He who does not meet these requirements must not only know what is identical and what is different: he must be able to determine both and build a strategy to resolve that problem. Success is rewarded twice: the concrete task is solved and in the course of its solution self-education takes place, for a person assimilates, if only partially, the general principles, rules and methods that are necessary in solving other tasks of this kind. The ability to cope with such tasks heightens a person's social status as a proponent of culture: as someone who has withstood the test he is ready for the higher school of semiotic arts which paves the way to the mysteries of semiotic being accessible only to the elect.

A world measured by the problem of identity and difference becomes more complex and diverse. One discovers that what is superficially identical is not identical deep down, in its essence, which often is the only important or even the solely important thing for man. In the same way, what is different in appearance can often mislead by revealing the basic identity in special conditions. Therefore, the world considered and illumined by this problem appears at once to be more differentiated and structured, but also more integral: everything that is different refers one back to the idea of identity and what is identical invariably has difference as it background.

At a certain stage in the development of any culture, even the most monolithic culture overwhelmed by prescriptions, principles and theories, there inevitably arises the need to come to grips with the problem of the "similar" and "dissimilar" and with the idea of comparison. But this situation is revealed with particular sharpness and inevitability in the contact between two or more different cultures and it reminds us of the reality, the absence of a "single" and homogenous culture and the presence of a "different" culture which one has to consider again and again in terms of identity and difference, a problem that has to be solved in practice.

The study of the Tower of Babel told in Genesis $(11,1-9)$ is exceedingly instructive. To all intents and purposes it is about the fate of a "single" language and a "single" culture (And the whole earth was of one language, and of one speech) that cannot be compared, related to anything, that cannot be judged, corrected or supported, or reproduced. An awareness of singleness, and not just unity, of being unique, the absence of anything that is different, consequently, the lack of alternative solutions naturally leads to the idea of self-sufficiency and infallibility, breeding pride which violates the boundaries set by common sense and the conditions of coexistence with what is different. This situation is fraught with the beginning of the fall which reveals itself as soon as the idea of construction ("superconstruction") emerges at the top and at the bottom, so to speak. On the one hand, people become less exacting towards themselves and their work, unconscientious and false ("And they said one to another, let us make brick, and burn them thoroughly. And they had brick for stone, and slime had they for mortar") (3) and on the other hand, they become arrogant, complacent and self-aggrandizing ("And they said, let us build us a city and a tower, whose top may reach into heaven; and let us make us a name") (4). When the Lord saw what the people of one language were up to, He said:

Behold, the people is one, and they have all one language; and this they begin to do: and now nothing will be restrained from them, which they have imagined to do. Go to, let us go down, and there confound their language, and they may not understand one another's speech. 
What is the meaning of that punishment? God did not abandon humans and did not withdraw his help, but, seeing that they are unprepared for genuine unity, he upset the natural unity of language-culture which, though being understood by its carriers, cannot be measured or compared with anything, and therefore leads to arrogance, an illusion of self-sufficiency and permissiveness and eventually to the loss of moral criteria and selfdeification. God helped bemused people by opening a new perspective to them. By embarking on the road of dispersion and differentiation of their former cultural and linguistic unity, by being locked in their own language and their own culture, people had to understand and come to love "their own," and, in the uneven surface "of their own" mirror to see the surrounding world, themselves and, eventually, others, who are of a different language and culture. These "others," as soon as they were noticed, and as soon as the fact that they were carriers of a different culture and language was understood, also became a mirror in which one could see not only "others" but also oneself, at least become aware of being different - in both merits and demerits which in their totality constitute the uniqueness of a given language and a given culture, something that ultimately becomes true of all the languages and cultures. Having found themselves isolated culturally and linguistically, separated but unable to live without each other, without contacts - friendly, neutral or hostile - people had to learn to assess the world and themselves by the instruments of their language and their culture, to control themselves, to become aware of the cultural and linguistic diversity and to understand its meaning, and draw the conclusion and turn towards or away from "others," to strenuously look for a chance in the wide sea of "the others" or to passively wait till the "others" find you, or to set oneself in opposition to everything "foreign" and build a tiny Tower of Babel with the resources of an imaginary single culture severing it from the common roots. The chief lesson of the Biblical story of the Tower of Babel is the choice of cultural and linguistic pluralism as the new road for man, the idea of a new unity (other than that given by nature) in diversity, of a new brotherhood of man. Once embarked upon that road, the overriding concern became, while knowing of "one's own," cherishing it and deepening one's own knowledge and creating new spiritual values, to understand a "foreigner," to assess him, to learn to live together, to exchange "native" and "foreign" values, to link both organically and naturally without undue haste, but without missing favourable opportunities, for delay can be fatal.

Living in a world where contact of cultures and languages form an exceedingly dense and traditional structure usually inherited from the distant past, it is hard to imagine the significance of the first stunning encounter of two cultures, two languages, and the immensity of the consequences of that encounter. It is important to bear in mind that such an encounter is always an experiment - witting or unwitting - and it is invariably a test of humanity, of predisposition to and a mission of humanity, unity in what is the most important for man. One has to beware of extreme cases when the encounter cancels itself, as if were, from the very beginning, when people of one culture destroy those of another culture (or mutually exterminate each other), ${ }^{6}$ without giving them a chance to express themselves and forfeiting that chance themselves, the opportunity to express their righteousness and denying oneself and the others an opportunity to gaze at each other. And yet fortunately, the most surprising (one might say, fantastic) encounters of people far removed from each other in geographical, linguistic and cultural space, bear out the primacy of the "anthropetal" element which reveals itself through the need for "selfless," disinterested contact, a kind of "sympathy" towards what is alien, and, of course, through the ability to establish contacts, i.e., to find a common ("identical") nucleus, sometimes even invisible and unconceived, but only intuitively divined contrary to all the visible, apparent differences magnified by fear. 
When, at the turn of the 15th and 16th centuries, Europeans set foot in the Americas, they encountered people who were beyond their world, across the boundless ocean, many thousands of miles away from the home of the explorers. And thousands of years earlier (in some cases apparently tens of thousands of years earlier) the distant ancestors of the Europeans and Indians who lived on the opposite ends of the Eurasian continent, in the West and in the East, were just as remote from each other, separated from each other by an overland distance so astronomical as to rule out any communication, even of an indirect, "relay" type. ${ }^{7}$ And yet, the first gesture of the first European who set his foot on the land of Amerindia was received and understood to the extent that it was necessary for both sides to establish contact, and the gesture elicited a reply which too was received and understood. Communication was established and passed the first test: it was proved to be possible. This was a bone "in humanity," in the human spirit (because in those conditions a gulp of water or a piece of bread offered by a "foreigner" were more important as spiritual than as material facts). And the very possibility and naturalness of establishing a link in "unnatural" conditions became the chief argument in favour of communication which could not be cancelled despite all the future episodes when what was natural and stemmed from real needs and genuine human requirements was obscured and distorted by what was "anti-human".

One should not, of course, idealize such encounters of cultures and peoples. Communication and acceptance of foreigness, tolerance of it, and acceptance of its raison d'être are natural, but so are suspicion, resentment, aggressiveness, hostility and struggle. But these "natural" instincts are different, they have different values because even the latter ("evil") kind of naturalness implies recognition of the fact that the world does contain something different, albeit something that evokes a hostile feeling. In this sense, and in the broadest context of the teleology of the human race on earth and the formation of the noosphere, contacts among peoples, languages and cultures are an achievement, a step forward, however complex and tragic their forms may be. Not the least of the reasons for this is that these contacts assert two elements, two "entities," two spirits, two consciousnesses - "native" and "foreign" - and thus invite a comparison with all the deeds prompted by such comparisons forming the body and soul of human culture which develops pluralistically in parallel, "near parallel," intersecting streams which nevertheless - in terms of cultural space - have approximately the same direction (and never opposite directions). ${ }^{8}$ Comparison is inseparable from culture and cult as its nucleus. Both serve the same ultimate goal. Indeed, the semantic structure of the words denoting these concepts is very similar and the words sound alike. Culture presupposes a selection, ${ }^{9}$ cultivation and tilling and establishment (the "thetic" function of culture), improvement, embellishment and worship (most notably religious worship). Corresponding meanings are inherent in the Latin verb colo from which comes the word cultur, literally something that has to be grown and cultivated. ${ }^{10}$ Hence the imperative mood of culture, its constant orientation on the future; one can only imagine it as complete in spe; but the completion of every particular cultural endeavour already marks the first step towards separating that part from the mainstream of culture. Comparison (cf. Latin com-paro $)^{11}$ in principle works in the same direction as culture. When something appeared and became noticed (pareo, compareo) or, more concretely, was established in the process of creation as a creature remembering its Creator and testifying to His creative potential, only then did conditions arise for com-parison. It is the same in later history: when "you" appear along with "I," when "alien" appears along with "one's own" this already gives grounds for comparison and only then does comparison become an ever-present factor. 
The results of comparison may vary. One can take a positive and accepting attitude with regard to what is "foreign" and then one says, "You are like us." (Or "We are like you.") A conclusion marked by a sense of satisfaction, even delight at seeing that statement being confirmed as true and positive. 13 Because, if you and $I$ are similar and comparable (and this can only be revealed through comparison) that is how things should be and what exists is not only posited but is positively good. 14 The identity revealed through comparison enhances the confidence of the validity of what is identical and its being part of the human order. Even though it does not offer a full guarantee that this is the only way things should be, there is still a greater sense of assurance compared to what is characteristic only of "one's own." Thereby the "native" and the "alien" are united because they support and reinforce each other in some ways.

However, one can take a different attitude to what is "foreign," a wary and suspicious attitude, requiring verification, reflection, unhurried forming of an opinion and until it has been formed, the "foreign" is sized up, taken into account, but deliberately avoided. Yet the very fact of scrutinizing involuntarily and subconsciously introduces one into the "alien" realm and insipiently prepares a rapprochement with the "foreign." If the "foreign" assumes the same attitude, then the odds are that an encounter will take place (or has already taken place) and that the consequences will be mutually beneficial.

In the worst case, there can be a negative attitude that rejects the very possibility and/or usefulness of relations with what is "foreign," and there can be hostility and hatred. In such cases the argument uses as a take-off point the empirically unassailable statement that "you are different from us," but being unable to go deeper, devoid of a breadth of inner experience, blinded by "one's own," people hasten to erect what to them seems to be an unchallengeable syllogism, "we live the way we do, and therefore we are good; you do not live the way we do, and consequently you are bad." The extension of this argument, given corresponding conditions, often (but not always and not necessarily) leads to attempts to eliminate the "foreign" - at least from the sphere of communication or - as a total safeguard - to eliminate it from everywhere and for always. While a negative attitude to the "foreign" does not in itself necessarily indicate ill will, of a certain lack of culture and the imperfection (primitiveness and subsequent atrophy) of the "comparison" mechanism 15 and does not fully cancel the positive impulses of comparison, the attempts to destroy the "foreign" even for the sake of "one's own" (perhaps especially due to this motive) invariably represent an evil and does harm both to the "foreign" and to "one's own." In this case comparison collapses, or rather those suffer a collapse who, being unable to use comparison, distort its inherent positive meaning and try to erect a Babel-like monster, an "anti-comparison," which confounds people and scatters them just like the fatuous, but unfortunate builders of the Tower of Babel were confounded and scattered by God.

The theme of comparison has another aspect to it. That language and thought are fundamentally linked is well known. Language provides thought with means of expression, and/or forms it, and it does so in time and sometimes in advance; moreover, language is not merely an instrument of thought, but also its content and meaning and its guide in scaling new heights. At any rate, all the apparent and expressed wisdom of the world is usually revealed to us through language, or, to be on the safe side, one could say that language is the most universal form of expressing this wisdom. But man has a way of forgetting the wisdom of past epochs and only language, if one accords its due attention, sometimes reminds us of this wisdom and of its role as a repository of wisdom. The Russian word for comparison, sravneniye, pinpoints an idea and a concept that is indispensable for a student of culture. It has two important meaning elements: first, more than one participant (subject or object) are involved in the action denoted by this word, 
$c f$. the prefix $c$ - that indicates togetherness and relatedness and the idea of equality, or ravenstvo (the root of the Russian word is -ravn-). The latter is particularly important in the context of this article. Two (or more) objects are not merely juxtaposed but they are compared (c-ravnivayutsia), i.e., they are mesured by an equal (or the same) yardstick. Also, the yardstick bears an affinity to what it is used to measure (something like the relationship between eye and colour, ear and sound, etc.), it identifies the equal even in what is unequal, or what it records as unequal, it looks for the causes of inequality and points to the arch-situation (or proto-situation) in which equality and differences are neutralized, reduced to naught, dissolved in identity. In the deep philosophical meaning, comparison is always informed with the notion of ideal equality (in the Platonic sense, i.e., of an object brought to its logical limit, a situation when its deepest potential is revealed), the search for a unifying, "equal" (ravnii) element for without it there is no terra ferma, everything becomes inchoate, comparison lacks principle outside the framework of ideal equality and the very word sravneniye, like the corresponding notion in the context of all-pervading differences, appears to be a contradiction in adjecto, a comparison of unequals. The linguistic lessons to be drawn from studying the structure of this word, far from being random, reveal a profound purposefulness and perhaps an equally profound element of providence. Both are exceedingly instructive in providing a solid benchmark in a diverse, changeable and disparate world which one might be tempted to take for chaos ruled by accident but for the solid frame provided by ravenstvo, which is implied in comparison (sravneniye) and follows from it. ${ }^{16}$

The links between comparison and culture are diverse: they mutually engender each other and there exists between them a cause and effect relationship in which they can swap places. The whole of culture provides material for comparison and any comparison is a fact of culture. Lack of space prevents me from elaborating on this link, but it would be safe to say that all cultures rely on comparison just as all artistic texts do (the most elementary kind of comparison, metaphor, symphor, metonymy, synecdoche, hyperbole, litotes, prosopopoeia, epithet, antithesis, etc., are essentially different kinds of comparison). The similar role played by comparison in culture and in the structure of a literary text stems from the shared need for comparison to create a second ("other") mode of expression, a different idiom, to form the bilingualism of culture and the artistic text in which the entities being compared constitute two modes of expressing the content which can be described as direct and indirect, "native" and "foreign." But the similarity of the role of comparison throws a sidelight on the similarity in the structure of the paradigm of comparison revealed in the text of culture and in a verbal literary text.

Looked at from this point of view, comparison plays the same role in both cases: it is a means to enhance the flexibility of culture and of the text by introducing an extra channel of communication; it offers yet another guarantee that the meaning of the text and its cultural background will be understood and that the understanding will be complete and accurate.

\section{NOTES AND BIBLIOGRAPHY}

1. One can of course mention more general and remote analogies and parallels which are essential and merit attention in some contexts, but not in this article. For instance, analogies to translation (which belongs to the realm of culture) can be found in the realm of nature, organic forms, the transiation or transmission of substance from generation to generation ("native" $\longrightarrow>$ "foreign") which presupposes the preservation of a measure of genetic similarity involving two different components with regard to which the resultant component is something distinct. In this case, like in translation, we deal with the paradox of likenessdifference in the transition from "one to another." In translation, these take the shape of a "foreign" language resp. culture and "one's own, native" language resp. culture, in the translation or transmission of the living substance in nature "one" and "the other" is realized in time, the generation of parents and generation of children, i.e. "us" and "them." 
2. The same bilateral links between components are present in the exchange of "genetic" information in the biological act of engendering.

3. "Whither shall I betake myself this January?... Am I drunk on closed doors? All these locks and latches make me scream./And I 'ah' with them knocking at some frozen wooden box./Give me a reader! a counsel! a doctor! / Oh, how I yearn for conversation on a cold staircase!" (January 1937)

4. Osip Mandelshtam (1967): Conversation about Dante, Moscow, p. 83 (in Russian).

5. The distinction between a sign and a non-sign is a special problem.

6. History attests to this. The proverbial plea to the conqueror to leave at least some of their people alive "for the seed," "to preserve the tribe" is not a folk hyperbole, but part of reality, the last attempt or argument in favour of preserving the physical existence of an ethnic "body" that could revive the soul of the culture when conditions are favourable.

7. As in Afanasy Nikitin's Journey Beyond the Three Seas. The journey from Tver to Bidar was very long and perilous, but the Russian explorer moved successively from country to country, from people to people, from culture to culture, from language to language, in short, from neighbour to neighbour which made for a smooth transition and protected him from "culture shock." Each of these "cultures," in speeding the traveller on his way, gave him a safe (sometimes not-so-safe) conduct.

8. This is not to suggest that the history of communication between peoples and cultures does not offer examples of an illusion of absolute, mutually exclusive oppositeness of the "native" and the "foreign," which leads to extreme actions. But this consciousness never met the inner reality of the spirit and has invariably been "evil," a delusion or self-delusion, a beclouding and bemusement of the spirit.

9. Cf. the folk etymological link between Latin colo II, cultum "to cultivate, till," etc. (cultus, cultura), and Latin colo I, colatum "to sieve, purify" (cf. colum "sieve," "filtre").

10. Latin colo II contains other important meanings such as "to live,", to "abide" (cf. cultus as "way of life"); "to apply oneself assiduously, to cultivate, to act", etc.

11. Cf. com-par "equal;" "comrade," "companion," "spouse."

12. "You" because "you" is always an interlocutor, a participant in a dialogue, a close "alien," a mirror of "I" that is to "you" what "you" are to "me." In this perspective, "he" is a distant "alien," at best a witness who can be discounted.

13. It is significant that the epithet "positive" is linked, at least in Russian, with the neutral, "tethic" verb polozhit" "to ordain," a key demiurgical act.

14. In the same sense as it is used in the Book of Genesis, $c f$. "In the beginning God created... And God saw that it was good."

15. The attitude of rejecting what is "alien" can in some cases attest to a pragmatic mindset and a loyalty to the habitual world. The crime lies not in a negative attitude to what is "alien," nor yet in the desire to reexamine the problem (though this is of course bad and suggests a certain deficiency in a given culture), but in acting according to such an attitude.

16. Note the Latin word for comparison, comparo, but also paro. The idea of equality ( $c f$. par, parilis, pariter, etc.) is however differently motivated in this case ( $c f$. Indo-European per "to penetrate," "to transfer," "to translate," an important meaning in connection with the role of translation and "equalizing" of languages and cultures as marked islands of meaning which are separate but need to communicate with each other, the mission that falls to him whom translates (Russ. pere-vodit) consciousness across the separating void) stressing the dynamic change of position, exchange, closing of a deal, etc. But in this case, too, the idea of comparison is linked to the idea of establishment, ordination (cf. codem vos pono et paro. Plautus or even res natura comparatae, Rhetorica ad Herennium, etc.) The concrete inner meaning of the verb to "compare" in Latin is further revealed through its actual (notably, folk-etymological) and historical links with the same words in the meaning of "to prepare," "arrange," "acquire," etc., and with pario I, "to give birth," "to produce" ( $c f$. pario II "to make equal," "to trade," etc.) and probably also pareo, compareo, "to appear," "to become evident," etc. (penetration, a break through a cover separating the invisible and hidden from the manifest).

\section{II - “ADJUSTING TO RUSSIAN MORES" FROM THE SEMIOTIC POINT OF VIEW}

(One source of Fonvizin's "Nedorosl")

The phenomenon in the title of this article arose in Russian literature in the $1760 \mathrm{~s}$ and was theoretically interpreted at about the same time by V. I. Lukin. It is not only an intriguing, but an essential episode in Russia's artistic life in the 18th century. Unfortunately, the phenomenon has not attracted serious study and has not generally been accorded the attention it deserves. And yet it expresses important characteristics of the 
Russian spiritual culture in that century and points to one of the main mechanisms of Russian Enlightenment of that epoch. The lack of attention or underestimation of the phenomenon has its roots in the established hidebound tradition which described the phenomenon as secondary, having to do with the literature of the "lower orders," addressed to lay audiences and being beyond the pale of Literature with a capital L. Part of the reason may be that the main proponents of that trend (Lukin, Yelchaninov, Yelagin, Veryovkin, and others) were not in the top league of writers (their writings scarcely survived into the 19th century). Meanwhile Fonvizin, who was a brilliant writer, was, by a fateful mishap, perceived almost exclusively in the macro-context of the Russian literature, outside the locus which was his cradle, the micro-context from which he drew the factual material for his work, and which determined its direction.

The problem of "adapting (or rendering) to suit Russian mores" is anchored firmly in the Russian cultural context of the 18th century (the time after Peter the Great) which was marked by amazing semiotic richness that manifested itself over a wide spectrum between simple allegory and subtle suggestivity. The "semiotic" element in 18th century Russian culture reveals itself in the "games" in which signs are replaced and arranged in elaborate compositions, corresponding rules ("grammar") are formulated, hierarchies of "conventions" are erected and "clues" to them are provided which open the door to the sphere of pragmatics.

The feature that runs through what would seem to be a literary (or theatricalliterary) concern is the inherent "intersemioticity" (theatre: literature, art: life, "native": "foreign," etc.). Of equal importance is the fact that intersemioticity manifests itself in the text, or rather, in a pair of juxtaposed texts - "foreign" at the input and a (supposedly corresponding) texts is fixed by the shift from a "foreign" to "native" culture which is perceived "here and now," and consequently can be interpreted as a cultural index, the judgement "native" culture is accorded in the face of a "foreign" culture, self-assessment which presupposes not absolute, but relative criteria. It is an act of self-identification in the face of a foreign text. All this has a direct bearing, of course, on semiotic pragmatics. ${ }^{1}$ A "native" text proceeding from a "foreign" one, but preemptively constructed with a view to Russian mores" presupposes not so much knowledge of the "consumer" as the shaping of a new kind of "consumer" (a viewer or a reader) intended for smooth, conflictfree assimilation of a "foreign" culture and its development on the basis of a "native" version of culture which, owing to the very conditions of its emergence, cannot but gravitate to an open type of culture.

"Adjustment to Russian mores" is associated, above all, with the name of Vladimir Ignatievich Lukin. A successful practising author (An Oaf Reformed by Love, Fusspot, etc.), he was undoubtedly a powerful theoretician, who set out his views on the contemporary drama and his ideas of what it should be like in the prefaces to his own and other writers' plays and in his famous letter to Yelchaninov. Lukin's role in democratizing drama and theatre, in introducing the Western repertoire, in advancing the concept of "rendering" and, finally, in finding a "Russian code for these renderings" was significant and undoubtedly positive in the cultural sense. Lukin was a shrewd tactician. Anticipating objections to "renderings" and even formulating them on behalf of his imaginary opponents ("it disgraces the translator to remake comedies, and therefore it is dishonest with regard to fellow countrymen. It is better to write one's own, genuine stuff or to do something useful," [114]). He was bold enough to become a "renderer" and state his opinion on that score:

there is a great difference between imitating and remaking. To imitate means to take a character or part of the content, or something very small and isolated; to render means to 
include or exclude something while leaving in and adapting to one's taste all the rest, i.e., the main element... [115]

Lukin's fervent support, in 1765, of the proposed "people's theatre" in Petersburg, accessible to the broad urban strata, attests to his awareness of the role democratic theatre, its repertoire, characters, idiom, etc., could play. In that respect he was, of course, ahead of his contemporaries.

The theme of "adaptation to Russian mores," though important in itself, also merits attention because it directly involves two other writers who have not previously been studied from this angle. I am referring to I. M. Muravyov-Apostol and D. I. Fonvizin. This article arose as a spin-off of a major work on Pushkin and Goldsmith in the context of Russian Goldsmithiana. I will not attempt even a brief summary of that work. Suffice it to say that it makes a detailed analysis of I. M. Muravyov-Apostol's play Oshibki, ili Utro Vechera Mudrenee (O) (St. Peterburg, 1794) which is the first attempt in Russian literature to render Goldsmith's comedy (NO) (She Stoops to Conquer, or The Mistakes of a Night). ${ }^{2}$ Leaving aside the description of the manner of "rendering" chosen by the translator (actually the book does not purport to be a translation and some students of the Russian play probably do not suspect that the comedy is a translation) ${ }^{3}$ it has to be stressed that while the relationship between $\mathrm{O}$ and NO is undoubtedly that of the original and the translation, even a comparatively precise one in places, $\mathrm{O}$ reveals many echoes with Fonvizin's Nedorosl $(\mathrm{N})$ which leave no doubt that Muravyov-Apostol was familiar with the text of Fonvizin's comedy. ${ }^{4}$

Among these similarities, those that stand out are the characters of Styopushka Balabanov ("a kin of Mitrofanushka") and Milonov (Milon in N) and others, which suggests that $\mathrm{O}$ was influenced by $\mathrm{N}$. The influence is manifested not only in the types of characters, the general pattern of action and the elaboration of the story, but in specific details. Here are a few examples taken at random. "Prostakov. It's odd how kin can be alike! Mitrofanushka is a spitting image of his uncle..." (cf. elsewhere) Straromyslov. "Oh! My sweetie-pie! My darling child! You take after the late Sidor Pafnutich!" (In both cases it is the father speaking about his son); the "brutish" theme associated with Skotinin (the name is derived from the Russian word for "cattle") and his relatives in N, in particular with Mitrofanushka, and Smirenin's evaluation of Styopushka "What a boorish notion!" ( $c f$. Milon. "What a boorish comparison!" referring to Skotinin's words; Fomka, the hairdresser fixing the periwig of Mrs. Prostakova and Senyushka the hairdresser who "combs" Staromyslova's hair; the theme of pigeon-lofting ("I think I'll go to the pigeon loft" / N/and "his only solace is pigeon lofting"/O/); St. Nicholas Day as an indication of time ("On St. Nicholas Day it will be two years since..." / O/cf.: "he will be 16 around St. Nicholas Day in winter"/N/); the implied opposition of an ignoramus to a learned man in $\mathrm{O}$ and $\mathrm{N}$; the relatedness of Staromyslov (O) and Starodum (N); there are also numerous common details as regards the son's reluctance to study and the arguments mother advances to justify that reluctance, etc. Finally, the emphasis both plays lay on the problem of education cannot be ignored. But this, of course, has more to do not with the common starting premises of the authors than with direct borrowing. ${ }^{5}$

The number of coincidences between the texts of $\mathrm{O}$ and $\mathrm{N}$ is so great and their nature reveals such an intimate acquaintance with the text of Fonvizin's comedy that the scholar is confronted with an unexpected and novel challenge. While text $\mathrm{O}$, published in 1794 , is undoubtedly linked with the text of Goldsmith's comedy NO written in 1771 and staged in 1773 , being a rendering of the latter, it is equally beyond doubt that the text was influenced by Fonvizin's $N$ written in 1781 and staged in 1782 which presupposes not only an acquaintance with $\mathrm{N}$, but obvious borrowings from it. When first approaching 
this knotty problem, the following alternative suggests itself: either $\mathrm{O}$, while using Goldsmith's comedy as the main source, also borrowed a good deal from Fonvizin's N (secondary source) to the extent that it was permitted by the structure of the main source and the standards of precision the translator set himself, or $\mathrm{N}$ and $\mathrm{O}$ both have Goldsmith's comedy NO as major sources (needless to say, the word "source" in the latter case docs not have quite the same meaning as in the former case, involving comedy O). Fonvizin's play, of course, is neither a translation, nor a "rendering" of NO in the sense that became established as a result of Lukin's literary and theatrical activities. To what extent Goldsmith's comedy can be regarded as a "source" of $\mathrm{N}$ is a question yet to be studied and only tentative and very general ideas on this score can be expressed at this point.

At this initial stage in the investigation, the fundamental starting assumption must be the "overcoming" of the alternative suggested by a "logical" analysis. In actual fact we find that the "parallels," "coincidences" and "echoes" between the elements of both texts ( $\mathrm{O}$ and $\mathrm{N}$ ) can be fitted into two categories: the most substantive coincidences from the point of view of plot, motives, story line, characters and their functions, macrosemantics, composition, etc., practically always have analogues in the English text of NO which can consequently be regarded as a common source for $\mathrm{N}$ and $\mathrm{O}$; the less important, "partial," usually "Russian-flavoured" coincidences which play a specifying and/or ornamental role do not have (or in most cases might not have) analogues in the English text and can therefore be plausibly explained as borrowings from $\mathrm{N}$ to $\mathrm{O}$. The general scheme of dependencies appears to be as follows:

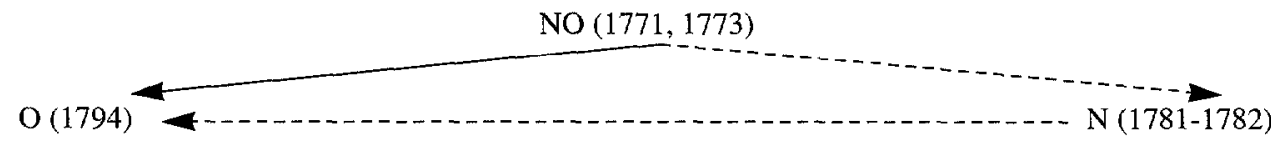

Legend:

$\longrightarrow-$ the relationship of the original and the translation

- - - > - the relationship of the "borrowing" type

(a historical-literary influence and, in the weak variant, "partial borrowing" due to acquaintance of the succeeding with the preceding, but not the typology of "pure forms")

Further on I will concern myself only with arguments that indicate that the author of $\mathrm{N}$ was acquainted with Goldsmith's comedy as revealed in the presence, in $\mathrm{N}$, of a whole range of features harking back to Goldsmith's play (NO).

The common nucleus of dramatic personae in the comedies being compared is a triangle consisting of symbolic characters: the Son - the Young Relative - her future Fiancé, i.e., respectively Mitrofanushka - Sofia - Milon and Tony Lumpkin - Miss Neville - Hastings.

These common "functional character" features can be stated more precisely and concretely to reveal a still denser layer of common traits.

The Son is a lazy good-for-nothing, who is reluctant and/or incapable of learning and prefers coarse pleasures - gluttony or wine, pigeons, dogs, horses, the inn, (in both cases, the Mother thinks of her son as a child - understating his age - who has allegedly a poor constitution and needs extra feeding and does not really need to study or join the civil service because he has a fortune and a noble title, and an opportunity to marry an heiress).

The Young Relative is an orphan living in the house of the Son's parents under their guardianship; when it transpires that she is rich the parents decide to marry her to their son (the Son is sexually indifferent to the Young Relative), but the "Young Relative" has 
an old amorous attachment which she keeps secret from the members of the family and which only comes out due to a surprise and accidental visit of the Fiancé; an unforeseen obstacle (the Young Relative being taken away) arises, but it is successfully overcome.

The Fiancé is a positive character, an antipode of the Son; he is associated with an older positive character (Pravdin/also Starodum/; Marlow and father); on the relations with the Young Relative who ends up by becoming his Fiancé, see below; generally an "intermediate" character with no negative traits (as revealed by the Prostakovs, Skotinin; Mrs. Hardcastle), he is no match in wisdom and experience to the others (Starodum, Pravdin, Marlow the father), but his position in the play's structure makes him a "sympathetic character ("a pure function").

The triangle of characters common to both comedies is naturally extended but in ways that also reveal a high degree of similarity. One can be said to be "endemic" - the Son's parents (the Prostakov couple, the Hardcastles) who are also the guardians of the Young Relative (the "parents" are differentiated: the Mother is a proponent of a "negative" programme which is criticized, the Father is either "positive" - Hardcastle - or relatively neutral and in any case derivative - Prostakov). The other extension is external: it is embodied by the positive characters outside the parental home which is the main setting for the action (Starodum, Pravdin, Marlow Sr.), these characters "help" both the Young Relative and the Fiancé because they are wordly-wise and fair.

To be sure, along with all these far-reaching and far-from-accidental coincidences in the set of characters and their functions in the two plays, there are also specific differences. But they are minimal, can easily be "figured out" and almost automatically predetermine the moves in the plot. Goldsmith's play differs from $\mathrm{N}$ in having a Daughter (Miss Hardcastle) who is a half-sister of the Son (Tony Lumpkin). $\mathrm{N}$ does not have such a character but instead it introduces a new character, the Uncle (Skotinin) who is also the brother of the Mother (Prostakova). This accounts for the "original" (differing) twists in the plots of the two comedies: the Daughter implies the presence of a second fiancé (Marlow Jr.) and the motive of a double wedding; the presence of the Uncle introduces the motive of love rivalry with the nephew (the Son); similarly, the Young Relative in Fonvizin's comedy (Sofia) blends as it were two female characters from Goldsmith's play, the two future brides (Miss Hardcastle and Miss Neville). This basic "characterfunctional" scheme allows for certain reconstructions and probabilities. A certain redundancy of Pravdin, remarked by the scholars who study N (Pravdin belongs not so much to the plot as to Fonvizin's ideological programme - N. I. Panina) springs from the fact that Pravdin is underloaded plotwise. The character does not quite pull its weight in the play. ${ }^{6}$

The "character-functional" scheme already goes some way towards determining the structure of the plot in each of the plays being compared. Not surprisingly, the plots are so congruent that they can be fitted to a single scheme (more precisely, as a "theoretically-multiple product" of plot elements that describes the plots both of $\mathrm{N}$ and NO fully and adequately). The scheme goes like this:

A provincial married couple ("parents") have a loutish Son and a Young Relative (an orphan girl) leading a miserable existence under the couple's guardianship. The unexpected arrival of "positive" characters ("from outside") reveals new information that changes the status of the Young Relative: she turns out to be an heiress and can dispose of her wealth and her fate, and on the other hand she has a Fiancé of whose existence she had not told her guardians (her own meeting with the Fiancé comes as a surprise to her). The upgrading of the Young Relative's status gives an idea to the Son's Mother: she wants to marry him to the heiress although the Son shows no enthusiasm for the plan. The plan, involving the kidnapping of the Young Relative by the Mother for her Son, or 
from the Mother for the Fiancé prompts secret actions which end in failure. Thanks to the efforts of the "older" and "positive" characters (Starodum, Pravdin; Marlow Sr., Hardcastle) a happy ending takes place. The Young Relative (also the Daughter in NO) is about to marry and the Mother who has suffered a fiasco in her matrimonial plans for her Son is punished by being separated from him.

This basic plot structure is cemented by highly characteristic common motives which do not inevitably follow from the plot. Here are examples in point. The kidnapping motive is realized in similar ways: a coach awaits the fugitives in a hidden place early in the morning (Prostakova. Make sure the coach waits at the back porch at six. - Mrs. Hardcastle. /Reads /... I'm now waiting for Miss Neville, with a post-chaise and pair, at the bottom of the garden...), but in both cases the plan falls through. There are similarities in the motive of the reading of the letter containing vital information on the Young Relative with the reader experiencing serious difficulties because his / her literacy is rudimentary. The Prostakovs and Skotinin refuse to read the letter and summon Mitrofanushka, who "has already started learning", to do the job, but he never gets around to reading the letter, whereupon the Young Relative (Sofia) offers to read it, but Prostakova objects "Oh, darling! I know you are a great one at reading, but I don't trust you very much. I think Mitrofanushka's teacher is coming. I'll ask him" though unable to read the letter, Prostakova snatches it away from Sofia: "You'd better give it to me." A similar situation occurs in Goldsmith's comedy when the letter is received: Tony (Still gazing). A damn'd cramp piece of penmanship, as ever I saw in my life. I can read your printhand very well. But here there are such handles, and shanks, and dashes, that one can scarce tell the head from the tail/... / A damned up and down hand, as if it was disguised in liquor. (Reading) Dear Sir. Ay, that's that. Then there's an M, and a T, and an S, but whether the next be an izzard or an R confound me, I cannot tell." Miss Neville, like Sofia in N, offers her Aunt to read the letter giving her motive as this: "Nobody reads a crap hand better than I" (Twitching the letter from her), $c f$. earlier remark from N. Almost snatching the letter. ${ }^{7}$

Another common motive is treating the Son as a child as a pretext for making him stay at home with his parents. Towards the end of $\mathrm{N}$ we learn that Mitrofanushka is old enough to serve in the army (cf. Pravdin / to Mitrofanushka/. I know what to do with you, my friend. The best thing for you will be to join the army). In Goldsmith's comedy it becomes clear towards the end (contrary to what Mrs. Hardcastle says about her Son's age at the start of the play, "he's not come to years of discretion yet," that Tony Lumpkin has already reached the age of 21 , the age of consent when he can make his own decisions. As it happens he can decide to leave his Mother and go to town (Tony, Of age! Am I of age, father?) ${ }^{8}$ Incidentally, the penultimate remark of Prostakova addressed to her son (And you! You are abandoning me! How ungrateful of you!) echoes Mrs. Hardcastle's description of her Son in similar circumstances: "My undutiful son!" and "Is this, ungrateful boy, all that I'm to get from the pains I have taken in your education?"

Starodum's concluding sentence, "Such are the fruits of evil mores" can be related to the words of Marlow addressed to Tony: "You see now, young gentleman, the effects of your folly..." In the same context, the description of the Mother also reveals similarities: Prostakova is referred to as an "evil fury" (cf. "old witch" with reference to Yeremeyevna) and Mrs. Hardcastle is described as a "hag" when the letter she intercepts is being read: "Dispatch is necessary, as the hag your mother, will otherwise suspect us" and almost the same words are used to describe the ritual gesture of the "old" and "wise" character that crowns both comedies - Starodum (holding Sofia and Milon's hands). Cf. Hardcastle (Joining their hands) (their being Miss Hardcastle's and Hastings' - V.T.) ${ }^{9}$ 
But the similarities between the comedies of Goldsmith and Fonvizin do not end with the "character-functional" or plot levels: they also cover the level that might be termed the "programmatic-ideological." Needless to say, the Russian writer, involved as he was in an important ideological and political game and equipped with an articulated programme ( $c f$. "Panin's Testament" drawn up at about the same time the play was written and staged or an original part of the "Brief Exposition on the Liberty of the French Gentry and on the Usefulness of the Third Estate") was more concerned with that level than Goldsmith. And then the Russian situation differed greatly from the English one (by comparison with Mitrofanushka and Mrs. Prostakova) the "illiterate" Tony and his Mother look almost like paragons of education and the subject matter Tsifirkin, Kuteikin and Vralman are drumming into the head of their pupil is very different in its level from the "Graeco-Latin" syllabus pursued by Tony of which some idea can be gleaned from the ditty he signs in "The Three Pigeons" inn, and the stakes in this ideological game, which spilled over into literature, were of course much higher. Finally, the personal social involvement of the Russian satirist was undoubtedly different from Goldsmith's, differences that were bound to be reflected in the two texts being compared, at the "programmatic-ideological" level.

And yet what is surprising is not the differences, but the similarities of the ideological programmes which are of course more difficult to prove in considering the question of the historical-cultural links between the two texts. I will therefore dwell on the comparison of these aspects only in very general terms.

Much of $\mathrm{N}$ is concerned with the subject of education. It is "played out" in the colourful scenes of Mitrofanushka's tutoring, in the reasoning of Starodum and Pravdin which is often rather vague, but sometimes fairly specific and containing important hints. 10 The subject of a nobleman's service has also come in for some attention. Unfortunately, the theme that exercised Fonvizin's mind more than any other ( $c f$. Starodum's remarkable conversation with Sofia/act 4 , scene $2 /$ in which the theme of duty attracts other important themes - virtue, conscience, dignity, happiness, education, employment, love of country, etc.) and on which the writer is most eloquent, has often been described as stilted and "overthought." But this evaluation ignored the depth and breadth of the treatment of that theme, its constructive pathos and the concrete and organic bonds between this theme and the diverse aspects of life. Two hundred years later the time has come for giving due to the allegedly tedious aspect of $\mathrm{N}$, to stop opposing it to the "realistic" scenes portraying "raw" life; it is high time to understand the moral and didactic thrust of the comedy which anticipated and presaged the views of Gogol, Dostoyevsky and Tolstoy; finally, it is high time we became aware of how much Fonvizin cared for Starodum ${ }^{11}$ whose role has been most heavily edited in stage productions and publications and the meaning that the author invested in that character. The letter to Starodum opens with the words: "I have to admit that I owe the success of my comedy, Nedorsl, to you. From your conversations with Pravdin, Milon and Sofia I have derived entire scenes which the audiences delight in hearing to this day" (A Friend of Honest People, or Starodum; $c f$. also Starodum's pronouncements in N about "a true sovereign" which seem to hark back to the problems of Seth).

In the whole range of moral and practical problems raised in $\mathrm{N}$ two interconnected questions stand out - education and duty. But these two questions were central to the "programmatic-ideological" aspect of Goldsmith's comedy although they are treated with less ardour and in a more reserved and altogether different tone. In both $\mathrm{N}$ and $\mathrm{NO}$ the graphically described result of the wrong kind of education is contrasted with an ideal of an enlightened young man grooming himself for the performance of duty, for civil service. Referring to the son of his old friend, Sr. Charles Marlow, Mr. Hardcastle, who 
wants to marry his Daughter to him, says: "the young gentleman has been bred a scholar, and is designed for an employment in the service of his country. I am told he's a man of an excellent understanding." The same sentiments are in one way or another reflected in other places in NO not to speak of Goldsmith's other works.

Although the above two questions are clearly given prominence, they are related to somewhat different things in the two texts being compared. For Fonvizin, the immediate context was the theme of the deprivation of "freedom," the despotic and cruel way in which the "evil" noblemen treated their serfs. In Goldsmith's comedy the problem of education is linked with the theme of overindulgence in fads and fashions (French, metropolitan), often to the point where people lose a sense of dignity ( $c f$. the dialogue between Father and Daughter at the beginning of the play). This theme is absent in Fonvizin's N: the Prostakovs and Skotinin are so coarse and brutish, so steeped in their crude lives and so bigoted that they are impervious to the outside world, and to fashions and incapable of imitating other models. But Fonvizin probably did not need to introduce this theme in $\mathrm{N}$ for his previous comedy The Brigadier is devoted entirely to it (this theme, so prominent in the Russian journals in the $60 \mathrm{~s}$ and $70 \mathrm{~s}$ of 18 th century, continued to be laboured a decade later).

Moreover, one can go further and suggest that by the mid-1760s Fonvizin was clearly thinking, vaguely at first, of a "summary" comedy, a "proto-comedy" from which sprang Brigadier and later N.12 That "proto-comedy" drew on the writer's personal impressions sometimes verging on the "biographical"13 and the impressions from his reading and theatre-going. Therefore, he kept fleshing out this common core with colourful Russian material and, on the other hand, consistently structured it in imitation of "foreign" schemes, whether it be Goldsmith's comedy NO or Holberg's comedy that was so popular in France (Jean de France) and which had been translated into Russian by I. P. Yelagin, who was Fonvizin's boss and protector at the time. ${ }^{14}$ By applying the scheme borrowed from Holberg to his "proto-comedy" he wrote Brigadier; and his acquaintance with Goldsmith's comedy led to another variant of the "proto-comedy," N.

If the above hypothesis is correct, the supposed "proto-comedy" already combined all the above-mentioned "ideological" themes, viz. education, civil service (the noblemen's duty), abuses, Franco-mania, which did not receive a full treatment in Brigadier and in N. Invoking early versions of the "proto-comedy" is instructive in yet another way as it gives insights into the evolution of the author's views on dramaturgy and into the comparison of $\mathrm{N}$ and NO. In the first edition of $\mathrm{N}$ one is struck by the absence of the character of a young girl, the future bride ("proto-Sofia"), a lacuna that can hardly be attributed to the fact that the text of that draft is not fully known (the important thing is that the character is not listed among the dramatic personae (in Brigadier, on the contrary, the instructive part is the presence of the pair Ivanushka-Sofia /cf. Mitrofanushka-Sofia in $\mathrm{N}$ and Tony Lumpkin-Miss Hardcastle in NO, with corresponding parental couples - the Brigadier and his wife, the Counsellor and his wife). This scheme anticipates the scheme of Goldsmith's comedy in some way and could easily be transformed into it. To accomplish that the Counsellor, Sofia's father, who is enamoured of the Brigadier's wife, Ivanushka's mother, has to marry her and then Sofia would have become Ivanushka's sister. While the text of NO suggests the following scheme of "transition." 
I.

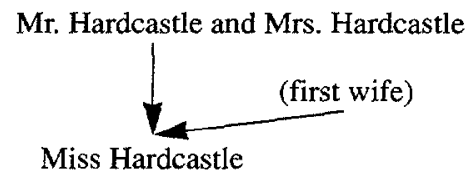

Mr. Lumpkin and Mrs. Lumpkin

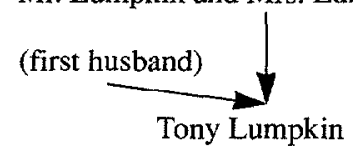

II.

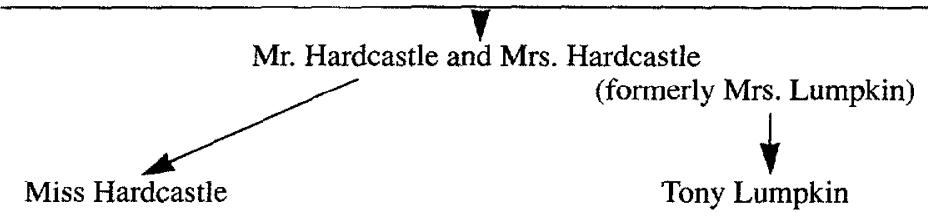

The "options" present in Brigadier could be reconstructed in a somewhat similar way:

I.
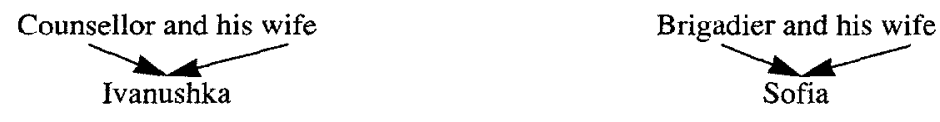

II.

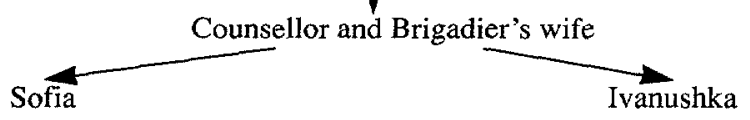

In both cases the "young female" character is associated with a future Fiancé (Mr. Hardcastle with Marlow - son and Sofia with Milon).

Thus, the "character-functional" scheme of Brigadier was already pregnant with a construction close to the scheme of Goldsmith's comedy. It cannot be ruled out that an awareness of the similarity as a result of acquaintance with NO led Fonvizin to abandon the idea of a second marriage that would have made Mitrofanushka Sofia's step-brother. That was easy to do not only because of negative reasons (to avoid too close a resemblance to the scheme of NO), but also because the "satirical" element in the portrayal of Mitrofanushka and the Prostakovs was so strong that it was impossible to imagine Sofia as their step-sister and step-daughter. Sofia, a "young female" character, a future bride, could only be rescued by a discovery that she was not a relative of the Prostakovs and Skotinin and her living in the Prostakovs' house was a mere accident, a sad necessity.

This line of reasoning, if pursued further, can easily lead us into the realm of typology and the "logic of possibilities." However, one should not forget the basic fact of the historical and literary relatedness between elements in $\mathrm{N}$ and Goldsmith's comedy, a fact that must now be considered to be established. Certainly, a comparison of the two texts bears out such a link.

Does this fact, then, overturn the commonly held thesis about the originality of Fonvizin's comedy? Does it refute the possibility of other sources, not mentioned here, to which specific fragments of $\mathrm{N}$ have been linked? It is hard to give a precise and verifiable answer to these questions. It involves too wide a range of problems to be profitably discussed here. The main aim of this article is to discover a "new" text that can be considered as a source of $\mathrm{N}$ (whether the sole source or merely one of many is immaterial too) and to validate that thesis. This is not to suggest that the aspects omitted here are 
irrelevant and that one has to confine oneself always to the comparison of texts without venturing into the external, non-textual sphere. The external elements surrounding the fact of $\mathrm{N}$ being partly derivative from NO can merely be indicated here.

The natural question that arises is, were there internal and external grounds and conditions for the acquaintance of the author of $\mathrm{N}$ with Goldsmith's comedy? The answer must be affirmative. Fonvizin developed an interest in reading and theatre early on in his life and much of his reading was in German and French. The atmosphere in his family, at school and university exposed him to culture, fostered a habit of learning and selfeducation in which translations played an outstanding role. Fonvizin began to translate early, fast and copiously and the range of materials he translated was very diverse. Fonvizin's talent was appreciated by Professor I. Reichel of Moscow University who helped to publish the young student's translations. Fonvizin was 16 when a large collection of his translations from Didactic Fables by Holberg was published (1761). It was followed by a series of translations and adaptations, Voltaire's Alzire (1762), The Love of Karita and Polydorus by Barthelemy (1763), Corion (after Gresset's comedy) (1764), Heroic Virtue, or the Life of Seth, the King of Egypt by Terrasson (1762-1768), Metamorphoses by Ovid (the translation has not reached us), Sydney and Silly by Arnault (1769), Joseph by Bitobet (1769) and others.

By the time he was 25, Fonvizin had become one of the most prolific and prominent translators in Russia. Of particular relevance to our theme is the fact that Fonvizin was a vivid exponent of a new trend in Russian translation practice: the language of his translations was light, modern, dynamic and undoubtedly addressed to wide readership. Most important, Fonvizin, like Lukin and Verevkin, took to rendering foreign texts adapting them to Russian tastes ( $c f$. Corion which has a "Russian-type" character, the servant Andrei, mentions Petersburg and Moscow and deliberately introduces elements of dialectal speech).

After moving to Petersburg, Fonvizin became a professional translator. In 1762 he became an official translator for the Foreign Collegium which was headed by N. I. Panin and later by I. P. Yelagin, himself a practising translator. Fonvizin found himself working together with V. I. Lukin, a leading proponent of drama based on "adaptation to Russian mores." Lukin's Works and Translations, published in 1765, could not have passed unnoticed by Fonvizin. Thus, in the 1760s there was formed, at the Foreign Collegium, a group of energetic translators ("renderers") of a new type who, having put out pioneering translations along these lines, were no doubt aware of the theoretical and practical implications of such "adaptations to Russian Mores." At about the same time Fonvizin developed a passion for the theatre. "Nothing in Petersburg aroused my admiration more than the theatre which I saw for the first time in my life. The effect the theatre produced on me almost defies description," wrote Fonvizin in his Confessions. ${ }^{15}$ In Petersburg, he regularly attends Russian, French and Italian theatres, maintains a friendship with I. I. Dmitrievsky and follows contemporary French drama.

His foreign trips and exposure to the new literature and new stage plays broadened Fonvizin's horizons and made him aware of new models. From what we know about Fonvizin before he wrote his two main comedies, his extraordinary perceptiveness and his knack for adapting a foreign text to "Russian tastes," and his extensive previous experience as writer and translator, the hypothesis about the "Western" antecedents of Brigadier and $\mathrm{N}$ is highly probable, indeed, one can say with certainty that Western connections and sources were important for him throughout his career. What is surprising is not the presence and significance of these connections, but the denial of such connections by some. 
From that point of view, the assessment of Fonvizin (outside the question of the originality of his work) given almost a century ago in Alexei Nikolayevich Veselovsky's famous book Western Influence on New Russian Literature, which has provoked much fair criticism, but even more unjustified slander and vilification, remains largely valid. Witness the following excerpts:

The author of Brigadier and The Minor is generally regarded as a satirist... But, to test the originality of his methods, it would be useful to gather the accusations of borrowing levelled at him; some indications, which began in the 20 s of the last century, have been added to, especially by the studies of Prince Vyazemsky and the bibliographical investigations of Tihonravov, and, as the reader sees, the list continues to grow. Fonvizin drew liberally on his observations of the social situation in contemporary France from the book Considerations sur les mours de ce siecle, 1752, from an indifferent article in the German magazine Literatur und Völkerkunde, partly from the Philosophical Thoughts of Diderot; La Bruyère, Duclos, Dufresny, Voltaire, La Rochefoucauld, even the innocuous dictionary of synonyms by Girard was poached for Nedorosl (The Minor), and the borrowings tend to turn up precisely in those places where the reader most expects original comical touches, for example the scene of Mitrofanushka's geography test in which Prostakova's advice is borrowed from Voltaire's story Jeannot et Colin... For our part, we might add to this long list the instances of Brigadier (especially the delineation of Ivanushka's character) being influenced by Holberg's comedy Jean de France; I can mention, too, another instance of poaching that recently came to my attention: one of the best parts of the satirical magazine, Starodum, or the Friend of Honest People, the correspondence between the landowner Durykin and Starodum... is, in general outline, and even in many expressions, drawn from the Collection of Satirical Writings by Rabener..., with the names Russified - all this despite Fonvizin's vehement protestations... that "this work totally excludes translations," that "no work printed anywhere can have a place in this book, in short, all these works are entirely original." Actually, those features of the satirical picture we would be inclined to think to be a portrayal of Russian life... turn out to be an accurate offset of German satire painted from life... If we add to these disguised borrowings the list of obvious translations and renderings... we would have to change our opinion about our writer. (Quoted from the 5th Edition, Moscow, 1916: 81-85.)

Paradoxical though it may seem, the only point on which A. N. Veselovsky is definitely wrong is in underestimating the role of foreign precept and example in the shaping of a native culture. Sometimes, a foreign culture provides the most effective idiom for describing one's own and serves as its catalyst. Granted Fonvizin was less scrupulous and careful than Lukin, he is bolder in his "undeclared" borrowings, which often verge on plagiarism, but Fonvizin succeeds in spanning the gap separating the foreign and native cultures more fully and swiftly and effectively. The $1760 \mathrm{~s}$ and $70 \mathrm{~s}$ brought an awareness of a huge gap between the levels of the European and Russian literature and doubts were expressed that Russian literature could provide an adequate vehicle for the ideas and imagery of the latter. The work of Fonvizin, Novikov and the Typographical Company, and of Karamzin, went a long way towards bridging that gap by the turn of the century and presaged the advent of a new period in the assimilation of Western literature in Russia associated with the names of Zhukovsky, Batyushkov and later Pushkin.

When looked at from that perspective, the discovery of yet another source from which that play borrowed elements can hardly diminish the significance of $\mathrm{N}$ in the literary and social life of the time and in the history of the Russian literature. However, a cataloguing of such facts of literary borrowing does enlarge our understanding of precisely what it is that Russian literature owes to that of the West, of the effects of the 
"inherent trait of Russian souls" not only to imitate, but also to assimilate, 16 of where Fonvizin drew the line between "foreign" and "native."

On the strength of the foregoing, Fonvizin's name can be included in the history of Russian Goldsmithiana. But much requires further study. Of particular use would be an answer to the question, how Fonvizin might have become acquainted with Goldsmith's comedy. Clearly, it might have happened between 1773 and 1774 and in 1780 (the publication of NO and N). One can perhaps shorten the stretch of time. Most probably, Fonvizin read NO in 1778 (beginning from February) during his month-long stay in Paris where he showed a lively interest in new trends in literature and theatre, social life and politics, met Marmontel, D'Alembert, Thomas, Franklin, saw Voltaire several times, visited the Academy of Sciences and Académie française, etc. (see his letters to relatives in which theatrical news and gossip about actors feature prominently). All this makes it likely that a French translation or production of the play (Elle s'abaisse pour triompher [var. vaincre], or Les Méprises d'une nuit) attracted the Russian writer's attention. Of course, one cannot discount the possibility that he became acquainted with the comedy in Panin's circle: their constitutionalism made important for them certain features of the English political and social set-up, notably the state of education which forms one of the subjects of Goldsmith's play). But these are only preliminary and tentative considerations.

\section{NOTES AND BIBLIOGRAPHY}

1. V. I. Lukin in fact wrote about it. Describing the satisfaction derived from the production of a French play and being aware that a straightforward translation into Russian would be much weaker, would fail to evoke the same feelings and would even "humiliate our actor," he asks the question, "What is required to redress the situation?" and he proceeds to give this answer: "I think the answer is to remake or to adapt to Russian mores in the theatre. One should seek, not so much to convey the beauty and strength of a foreign writer, as to correct faults. Precise translation is for reading and for showing the author the way he is in order to convince the readers who are not proficient in languages that he has deserved the praise of those who know about the theatre by a vivid portrayal of his compatriots, and what we should offer for viewing to our people with a similar force and truthfulness." (From a preface to Rewarded Constancy, see the works of V. I. Lukin and B. E. Yelchaninov. St. Petersburg, 1868, p. 116.)

2. The play was first performed on December 15,1794 or, according to other sources, on September 20,1795 in the Derevyanny Theatre.

3. The Russian text of $\mathrm{O}$ preserves the plot scheme of $\mathrm{NO}$, the sequence of the main motives and turns in the plot, all the main dramatic personae. Moreover, many extracts of $O$ have correspondences in the Russian text. It can safely be described as a rendering of the English comedy representing an attempt to "adapt it to Russian mores," and the English text is not merely a "source," but the original of the Russian text O. The Russian play draws a clear distinction between what is borrowed and what is not. A master of language and style, Muravyov-Apostol never errs on the side of literalisms and takes the liberty of deleting "too English" places (e.g. the song of Tony Lumpkin) and introducing "Russian" details and Russian flavour, and constant topical references that had nothing to do with the English text ( $c f$. Staromyslov's colourful account of the new-fangled pursued by his neighbour, Count Vysokoparov). The Russian often strikes one as vernacular.

4. Some of these are mentioned in the article by I. A. Kubasov. "The Dramatic Experiments of I. M. Muravyov-Apostol." Ioryas, vol. 8, 1904, book 4, p. $11 \mathrm{ff}$.

5. Several facts attest to I. M. Muravyov-Apostol's interest in the problem of education. In this context, one might recall the start of his literary career when he translated and published La Chetardie's Instruction to the Young Gentleman, or The Image of a Worldly Man (St. Petersburg, 1778).

6. In principle, he could have become a fiancé of the Prostakovs' daughter, Mitrofanushka's sister, who, however, is not in the list of the dramatic personae. The Prostakovs are too "negative," odious characters to have a daughter who is a match to Pravdin.

7. It is interesting that the text that is often thought to be an early variant of $\mathrm{N}$ (pre-dating Goldsmith's comedy) begins with Ivanushka's (the future Mitrofanushka's) inept attempts to read. See "An Early Comedy of D. I. Fonvizin. First Edition of Nedorosl." Publication by G. M. Korovin. Literaturnoye naslediye, 9-10, Moscow, 1933, pp. 243-263. A summing up of the debate on the authorship of the text can be found in V. D. Rak. Was Fonvizin the author of the Manuscripted Nedorosl?" The 18th Century. Leningrad, 1983, book 14, pp. 261-291. 
8. $C f$, the Epilogue ("to be spoken" in the character of TONY LUMPKIN): Well - now all's ended - and my comrades gone,/Pray what becomes of mother's only son?/a hopeful blade! - in town I'll fix my station / And try to make a bluster in the nation...

9. The list of coincidences can easily be multiplied. $C f$. the theme of the Son's "weak" health in mother's speech; the Son's hobbies; attitude to learning; the fact that the Son's traits run in the family (cf. Prostakov. "It's odd, isn't it, how kin can resemble kin. Mitrofanushka is a spitting image of his uncle." and Mrs. Hardcastle. "My boy takes after his father, poor Mr. Lumpkin, exactly," etc.

10. Cf. "Sofia. I've been waiting for you, Uncle. I've been reading a book. Starodum, What book? Sofia. A French one. Fénelon. About the Upbringing of Maids. Starodum. Fénelon? The author of Telemaque? That is good. I haven't read this particular book. But you should go on reading it. He who wrote Telemaque will not corrupt mores by his pen. I am chary of latter-day sages. I've read all their works translated into Russian. They do much to eradicate prejudice, but they uproot virtue too..." The problem of education (model education) was undoubtedly the subject of discussion with the Panin brothers. On 18/19 September, 1778 Fonvizin writes to Pyotr Ivanovich Panin from Aachen: "Upbringing in France is confined to instruction. There is no master plan for education and youngsters are taught, but not educated... So, as regards education, France is no superior to other countries. It has as many flaws as elsewhere, plus a thousand times more charlatanism." See also some echoes of this theme in N. I. Panin's Testament.

11. Fonvizin's reminiscences about his father Ivan Andreyevich reveal some "Starodum" features. It is significant that such a human type had already been presented to the writer in an early translated version of Corion ( $c f$. the character of Menander as a distant harbinger).

12. This is no place to elaborate on this idea, but suffice it to mention the link between the "first" edition of $\mathbf{N}$ (and the final one) and Brigadier ( $c f$. "common" and similar characters: Ivanushka, Sofia, to some extent Dobrolyubov-Dobromyslov, Milon, Milovid, etc.) and the closeness of the "first" edition of N to Brigadier ( $c f$. Ulita Abakumovna - Akulina Timofeyevna); $c f$. such names as Starodum, Prostoserd (: Prostakov) in the extract "Comedy written in Fonvizin's hand" and mentioned in Vyazemsky's book (pp. 273-276).

13. $C f$. the well-known words N. I. Panin addressed to the author of Brigadier: "I see that you know our Russian ways very well, your Brigadier's wife is akin to everyone; no one can claim that he does not have such an Akulina Timofeyevna, or a grandmother, or an aunt, or some other relative."

14. A Russian Frenchman, a translated comedy staged at the Court Theatre in 1764-1765, shortly before Brigadier, has not reached us. Poroshin made this entry in his diary for October 17, 1765: "In the evening went to see a comedy (Pavel - V.T.)... The comedy was Jean de France, in Russian... Her majesty praised the big comedy and said only those who recognize themselves in it could fail to be moved by it that it tells unchallengeable truths; that the translation is very free and bold, and is cleverly adapted to our customs: the translator was Ivan Perfilievich Yelagin. Her Majesty laughed especially when the kitchenmaid sang a French song and the French Ivanushka was so moved that he wept and dropped to his knees. The comedy was not accorded the same approval in our box." (S. Poroshin. Notes... St. Petersburg, 1844, p. 465.) The comedy ran for some time. However, the Russian audience could hear and see versions that were closer to the original. "Was at the German Theatre today. The play was Jean de Paris. The opera made me think of happier times of my life," wrote N. I. Turgenev in his diary on Dec, 26, 1816. And this, from Fonvizin's letter to his relatives (Paris, April 1778): "If you thought we would be enchanted by other lands, you were mistaken. Withal, I am very glad to have seen other lands. At least they cannot impose Jean de France on me." The link between this play and Brigadier is beyond doubt ( $c f$. Sofia's remark about Ivanushka: "A Russian Frenchman generally had no regard for anyone but himself and the French.")

15. An inaccuracy may have crept into this statement. According to other sources, Fonvizin was introduced to the theatre still earlier, in Moscow, where he performed on stage himself.

16. In his well-known article in Zritel, P, A. Plavilschikov wrote: "To imitate means to do the same as you see in whom you follow: in this action the thought does not grasp the essence, but merely the surface and then a person is a blind imitator. To assimilate means to gain insight, to reach to the foundation and clearly grasp with one's mind the whole essence: in this case a person is himself a creator and may surpass his teacher." $C f$. his conclusion: "A Russian can assimilate everything." 